\title{
The Investigation Process Prevention And Eradication Of Narcotics Investigator To The Criminal Abuses By Police
}

\begin{abstract}
Ali Murtadho ${ }^{1}$
Abstract. Narcotics abuse is a transnational crime that is done by using a high modus operandi, advanced technology, and supported by jarigan organized. Narcotics are also considered an extraordinary crime because of the impact and the dangers posed to health damage as well as disorders of the nervous system of human, narcotics on one side are the drugs or substances that are useful in the field of medicine and the development of science and on the other hand can cause dependence highly detrimental if abused. Therefore, it is necessary to prevent and fight against the crime of abuse in the illicit traffic of Narcotics. Given the extraordinary crime then categorized the crime of Narcotics regulated more specifically in the Narcotics Act No. 35 of 2009 on Narcotics. In the prevention and eradication of Narcotics Police have an important role in it. In addition to enforcing the law, the police are also expected to minimize the prevention and guidance prior to the crime of Narcotics. As a form of law enforcement committed the offenses Police Narcotics abuse is to take action in the form of an investigation. Intent and purpose of the investigation is done to make light of a criminal offense to known suspects and to provide legal certainty and a sense of justice to citizens.

Keywords: Process; Investigation; Eradication; Narcotics; Police.
\end{abstract}

\section{Introduction}

Often we hear about the dangers of abuse of narcotics which have been the problem as well as the attention of the government in combating and preventing the crime of Narcotics. Narcotics Crime classified as extraordinary (exstra ordinary crime) because the impact and danger caused by abuse of narcotics damage the human nervous system that can lead to dependence and even can be a source of disease that later ended in death. Narcotics abuse is a problem that not only the responsibility of governments, but also the responsibility of the entire society to be active in combating and eradicating illicit traffic of narcotics in Indonesia. Basically Narcotics are used for treatment of materials and the interests of the development of science.

Narcotics are substances that can cause certain effects for those who use it to put it in the body. The influence of the body in the form of anesthesia, pain relief, stimulation spirit and hallucinations or delusions. The nature met and known in the medical world and used for the treatment of human interests, such as in the field of surgery for pain relief. $^{2}$

The more widespread circulation and abuse of narcotics as well as to prevent and also to eradicate the criminal acts of Narcotics, the state present in these efforts namely through law enforcement officers, one of which is the Police. Penegkan law on criminal acts committed by the Police Narcotics are investigating criminal narcotics. Narcotics Investigations of criminal offenses by police was conducted by investigators Drug

\footnotetext{
${ }^{1}$ Students Master Program (S2) of Law Faculty of Law UNISSULA email alimurtadho2007@gmail.com

${ }^{2}$ Soedjono. D. 1987 Hukum Narkotika Indonesia Penerbit Alumni Bandung p. 3.
} 
Investigation Unit at the level of either the Police Headquarters ( $\mathrm{HQ}$ ) Police, Police, and Police.

In the prevention and eradication of drug abuse, the police have a lot to take actions ranging from arrest, detention, seizure, search of the suspect who subsequently do justice to account for alleged acts. However, it turns out these efforts do not necessarily deter the perpetrators of pidan Narcotics, as seen when the convict is serving a sentence in a detention center, they still can make transactions such as Narcotics circulation of halted trading transaction up to the user or as a city. With the existence of the incident shows that Indonesia is in an emergency Drugs, not only among the usual msayarakat artists but also entangled in the crime of Narcotics.

The principal tasks of Police based on Act No. 2 of 2002 on the police is to protect, shelter, and serve the community, enforcing the law and maintaining security and public order. ${ }^{3}$ Law enforcement is the effort made by law enforcement to handle a criminal case in order to realize the rule of law that reflects the sense of justice. In the law enforcement itself consists of various elements of law enforcement from the police, judiciary, Judge, and correctional institutions that are interconnected to one another in the system performance. Dimuali law enforcement process of investigation by the police, prosecution by the attorney general, justice by the judges, correctional and penal institutions. In this case I will discuss law enforcement against narcotic crime in the investigations conducted by the Drug Investigation Division investigators, so in this study were more likely in the material handling Narcotics criminal case under investigation.

From the background of the problems above, the formulation of the problem is taken is: How does the process of criminal investigation by the Narcotics Police Investigator?; How the prevention and eradication of narcotics by the police investigation?

\section{Research Methods}

The type of approach used in this study is a sociological juridical approach, which in addition to using the principles and legal principles in reviewing, view, and analyze the problem, the study also reviewing how its implementation in practice. This study examines the enforcement of laws against the crime of Narcotics in the process of investigation by the police. In legal sociological juridical research conceptualized as an empirical phenomenon that can be observed in real life. ${ }^{4}$

In this study the authors use a type of type of research is descriptive analysis, namely troubleshooting procedures examined by describing and analyzing the situation, the subject or the object of the research can be a person, institution, or society which are now based on the facts available. Data were collected by using secondary data is data obtained from the study of literature (library Research), which can be books, scientific papers, case law, legislation, and other sources.

\footnotetext{
${ }^{3}$ Act No. 2 of 2002 on the Indonesian National Police article 14.

${ }^{4}$ Soerjono Soekamto dan Sri Mahmudji 2001 Penelitian Hukum Normatif Suatu Tinjauan Singkat Raja Grafindo Persada Jakarta p. 13-14.
} 


\section{Results And Discussion}

\subsection{Narcotics Crime Investigation Process By Police Investigators.}

According to the Law of Criminal Procedure Code the investigation is a series of actions the investigator to search and find the evidence and the evidence is made bright suatau criminal offense in order to find the suspect. Investigations of criminal offenses by the Police Narcotics carried out based on the fulfillment of at least two items of evidence, namely the testimony of witnesses, expert testimony, letters, instructions, and the testimony of the defendant. ${ }^{5}$

In the process of criminal investigation Narcotics there are several steps that must be passed in order that the investigation in accordance with the procedures and legislation. The stages are adaah A.1. Legal basis

The legal basis is that underlie any action by the investigator to perform a forced effort in terms of making light of a crime. The legal basis in the process of criminal investigation Narcotics are:

- Article 8 paragraph (3) and Article 10, paragraph (1) Criminal Procedure Code.

- Act No. 2 of 2002 on the Police.

- The Regulation No. 14 Of 2012 on Management of Investigation Crime.

- Act No.35 Of 2009 on Narcotics.

\subsubsection{Investigation plan}

In order for the investigation to be achieved as expected, then the need for a careful planning so that the results are achieved in accordance with the intent and purpose that has been prepared. Police chief investigation plan based regulation No. 14 Of 2012 on criminal investigations management intended to penydikan conducted in a professional, effective, and efficient. Investigation plan shall include: ${ }^{6}$

- The number and identity of the investigator.

- Goals / targets of investigation.

- Activities to be carried out in accordance investigation stage.

- The characteristics and anatomy of cases to be investigated.

- Completion time based on the weight of the case.

- Budget needs investigation.

- Completeness administrative investigation.

The underlying administrative investigation conducted investigation is a police report, a warrant of tasks, reports the results of the investigation, a warrant investigation, notification letter commencement of the investigation,

\subsubsection{The Purpose Of Investigation}

The purpose of investigation itself merupaan peak of what is expected by the investigator, of the various stages that have been done then the purpose of the

\footnotetext{
${ }^{5}$ Act No. 1 of 1981 About the Book of the Criminal Law Article 84.

${ }^{6}$ Police Regulation No. 14 of 2012 on Management of Investigation of Criminal Acts chapter 17.
} 
investigation was to find evidence and making light of a crime with the intent and purpose known to the suspect as the person who should be accountable for his actions.

\subsubsection{Target of Investigation}

Targets in the process of criminal investigation Narcotics are:

- People, namely the criminal narcotics as the party responsible for the crime of Narcotics. Next is the witness, the person who knew, heard, felt, saw firsthand the events alleged criminal acts. in the process of investigation, the witnesses were questioned by investigators in the form of minutes of the examination of witnesses and so does the same as the suspect.

- Events, namely criminal case in the form of abuse of narcotics.

- Place / time of occurrence of the crime of Narcotics.

Investigators for the sake of the investigation of criminal Narcotics accordance with Article 76 paragraph (1) of the Law on Narcotics Number 35 Of 2009 on Narcotics, have penangkan time for $3 \times 24$ hours to be able to determine the status of a person as a suspect who allegedly melakuakan not criminal narcotics. ${ }^{7}$

If within $3 \times 24$ hours investigators can not find at least two items of evidence to establish a person as a suspect, then based on the provisions of the legislation case disqualified by law and sseseorang arrested should be released because there is no strong legal basis to show that tersebuut person reasonably suspected as a criminal offense.

\subsection{Prevention and Eradication of Narcotics In The Process Of Investigation By The Police.}

Drugs which is a continuation of narcotics, psychotropic substances and other additives are medicines, materials, or substances and not classified as food if drunk, smoked, swallowed, or injected affect especially the brain and seraing cause dependence. As a result of the brain to change (increase or decrease), as well as other organtubuh vital functions (heart, circulatory, respiratory, and others). ${ }^{8}$

In the framework of the prevention and eradication of narcotics, the Indonesian National Police (INP) has taken various steps to be able to minimize the occurrence of the crime of abuse of narcotics, one of which is through law enforcement in the form of an investigation into the crime of Narcotics. Investigations conducted by the police intended to ensure legal certainty and provide good benefits to the community or to the suspect. Some law enforcement efforts that do the police in preventing and combating the crime of Narcotics are as follows:

\section{- Penal Efforts}

One of the efforts made by the police in pencegahaan and eradication of Narcotics is doing enforcement (repression) is to conduct an investigation that aims to make light of a case in order to find who the suspects. Police conducted the investigation will determine who the perpetrator or criminal suspects hereinafter Narcotics suspects

\footnotetext{
${ }^{7}$ Act Number 35 of 2009 on Narcotics article 76 paragraph (1).

${ }^{8}$ Sri fortune "Drug Prevention Among Youth" Pwiyatan Ilmiyah Magazine Vol: XXI No. 1 (2014) url: http: // download.portalgaruda.org / article.php.hal.23.
} 
will undergo further legal proceedings the prosecution and the judiciary in court. Police repressive measure is another step to keep the public from the threat of factual happened to give decisive action so as to create a deterrent effect. Investigation in Act No. 35 Of 2009 on Narcotics regulated in article 81,84,85,87,88, and $90 .^{9}$

\section{- Non Penal Efforts}

In Narcotics abuse prevention conducted by the police other than the prosecution is to provide guidance (preemptive) and prevention (preventive).

\section{- Pre-emptive effort}

Preemptive is a policy that sees the roots of the main problems the causes of crime through social approach, situational approach, and a civilized approach to eliminate the element of the potential for interference. Pre-emptive efforts by Polri begins with providing guidance, counseling, socialization, and appealed to the public to raise awareness and a willingness to live healthy. Preemptive efforts are more likely to emphasize to the public to understand, fix themselves to stay away and menindari abuse of narcotics. These undertakings also carry out educational activities with the goal of eliminating the opportunity factors, drug-free lifestyle and lighting early against drug abuse. ${ }^{10}$

\section{- Preventive efforts}

Preventive measures ie preventive measures on the incidence of interference threshold (police hazard), so as not to continue to be a real nuisance or threat factual. Narcotics Treatment requires apparatus and definite rules for Narcotics is a criminal offense that is difficult to eradicate. ${ }^{11}$ In this prevention police officers deployed to the region to anticipate and conduct raids on suspicious places, places potentially used to store, produce, and buying and selling drugs. Points are often targeted for instance are nightclubs and other enclosed spaces Police presence is deemed necessary in order to prevent abuse of narcotics. Preventive efforts are aimed at healthy people who are not familiar with the drug in order to know the ins and outs of drugs that are not interested to abuse it. ${ }^{12}$

Aside from the prevention of another attempt by Polri is cooperating with related agencies such as the National Narcotics Agency, educational institutions, religious leaders, community groups untukmendeklarasikan organizations on the prevention and abuse of narcotics.

\section{Closing}

\subsection{Conclusion}

In the prevention and eradication of narcotics, Police law enforcement has an important role in it among which take action in the form of investigations and coaching is done to

\footnotetext{
${ }^{9}$ Sasangka Day 2003 the Narcotic Drugs and Psychotropic Substances in the Criminal Code (Bandung: Mandar Maju) p. 148.

10 Bhakti Jayadi "Prevention and Eradication of Drug Abuse" http: //www.academia.education/ $14,530,762$.

${ }^{11}$ Lydia Herlina Martono et all 2008 Peran Orang Tua Mencegah Narkotika Balai Pustaka: Jakarta p. 93.

12 https://jauhinarkoba.com Some Efforts in Combating Drug Prevention.
} 
prevent the occurrence of the crime of Narcotics before. Thus from the above discussion of the problem, the authors conclude that the police in the prevention and fight against the crime of abuse of narcotics is through the efforts of the penal and non-penal. Police penal efforts made by way of action is to investigate such criminal case of Narcotics. Meanwhile, in an effort to non penal, police conduct training in the form of counseling, socialization, and educate the public about the effects and dangers of abuse of narcotics.

\subsection{Suggestion}

Preventing and combating abuse of narcotics is not only the responsibility of the police officers but are the responsibility of the entire people of Indonesia. Therefore, in order to prevent and eradicate abuse of narcotics can be effective, it should be any state institution or organization to participate in the prevention and eradication of the abuse of narcotics.

\section{Bibliography}

[1] Soedjono. D. 1987, Hukum Narkotika Indonesia, Penerbit Alumni, Bandung

[2] Sutrisno Hadi, 1979, Metodelogi Research, Yayasan Penerbit Fakultas Psikologi Universitas Gajah Mada, Yogyakarta

[3] Soerjono Soekamto dan Sri Mahmudji, 2001, Penelitian Hukum Normatif Suatu Tinjauan Singkat, Raja Grafindo Persada, Jakarta

[4] Hari Sasangka, 2003, Narkotika dan Psikotropika dalam Hukum Pidana, (Bandung:Mandar Maju)

[5] Lydia Herlina Martono et all, 2008, Peran Orang Tua Mencegah Narkotika, Balai Pustaka: Jakarta

[6] Act No. 2 Of 2002 on the Indonesian National Police

[7] Act No.35 of 2009 on Narcotics

[8] Act No. 1 of 1981 on the Law of Criminal Procedure Law

[9] Police Regulation No. 14 Of 2012 on Management of Investigation Crime

[10] Sri Rejeki, "Penanggulangan Narkoba di Kalangan Remaja" Majalah Ilmiyah Pwiyatan, Vol : XXI, No: 1, (2014), url:http://download.portalgaruda.org/article

[11] https://jauhinarkoba.com, Beberapa Upaya dalam Pemberantasan Pencegahan Narkoba.

[12] Bhakti Jayadi, "Upaya Pencegahan Pemberantasan dan Penyalahgunaan Narkoba", http://www.academia.education/14530762. 